\title{
ASSESSING THE IMPACT OF ERP IMPLEMENTATION IN THE SMALL ENTERPRISES
}

\author{
Justyna PATALAS-MALISZEWSKA \\ University of Zielona Góra, Poland \\ e-mail: j.patalas@iizp.uz.zgora.pl
}

\begin{abstract}
For a SME (small and medium-size enterprise) to operate competitively in an international and local market, it is necessary for it to deal with its tasks in an efficient and practical way; this can be achieved by the systematic analysis of the undertaken tasks in relation to the company's organizational and economical ability for their completion. The author suggests in this paper that the assessment of such an implementation depends on a firm's intention to use the ERP system to achieve strategic goals. The author discusses the issue of the Balance Scorecard method being used to assess the impact of an ERP system implementation on the performance of a small service enterprise. Using a research results, the author illustrates the possibility to assess the implementation of an ERP system in the small enterprises.
\end{abstract}

Keywords: ERP systems, Balance Scorecard, assessment of the implementation of an ERP system.

\section{Introduction}

The fact that ERP (Enterprise Resource Planning) systems are in demand as a support tool in management is proven by their dynamic development and a significant growth in their sales (Al-Mashari et al. [1]). Since all companies, including small and medium-size enterprises, can buy the same software, it can be clearly argued that the software itself is not the sole source of competitive advantage (Davenport [7]). It follows from the theory of competitive strategy that, if an organization chooses to implement an ERP, the organization will seek ways to derive strategic value from the ERP (Mata et al. [18]). Many organizations follow a change of management plan in which the strategy is changed before any complementary changes in people, processes, and technologies are implemented (Austin et al. [3], Lassila and Brancheau [14]). An ERP system opens new opportunities for strengthening a distinctive strategic position (Poston and Grabski [20]). For an SME (small and medium-size enterprise) to operate competitively in an international and local market, it is necessary for it to deal with its tasks in an efficient and practical way; this can be achieved by the systematic analysis of the undertaken tasks in relation to the company's organizational and economical ability for their completion.

The post-implementation phase of an ERP system is an understudied research topic (Gattiker and Goodhue [9], Staehr et al. [25]). Several authors (Markus and Tanis [17]) indicated that the Balanced Scorecard (BSC) (Kaplan and Norton [11]) might be the most appropriate technique for evaluating the benefits of an ERP systems. Rosemann and Wiese frame the application of the BSC method to ERP systems as a form of strategic management of an ERP system (Rosemann and Wiese [24], Rosemann [23]). The author discusses the issue of the BSC method being used to assess the impact of an ERP system implementation on the performance of a small service enterprise. My notion of the success of ERP systems is motivated by using the Balanced Scorecard method. I suggest that the assessment of the implementation of an ERP system depends on a firm's intention to use the ERP system to achieve strategic goals. This article addresses the following research questions: Does the use of BSC allow to measure the achievement of strategic business objectives assumed by the implementation of an ERP system?

Enterprises functioning in the market economy have to implement changes in the systems of organization and management that they use (Patalas-Maliszewska and Krebs [21]). This paper examines the long-term effects of ERP system revisions using the Balanced Scorecard method (BSC) for SMEs, the information is based on the research results (survey in six selected companies). The next section presents a review of the appropriate research. It next shows that an ERP system impacts the strategic goals of a firm and that four Balanced Scorecard dimensions are applicable to assess the benefits and measure the value-added contributions of ERP systems. The paper closes with a table of the correlation between defined indicators and measures of strategic impact to achieved from the implementation of an ERP system. 


\section{The Balanced Scorecard as a method for assessing the implementation of an ERP system}

Measuring the business value of IT investments has been a major challenge for researchers and professionals (Dehning and Richardson [8], Kohli and Grover [13]). Aral and Weill [2] classify IT investments into four different types, according to their strategic purposes: (1) infrastructure investments, (2) transactional investments, (3) informational investments, (4) strategic investments. The author suggests that the small companies need to be assess by the implementation of the ERP system in the strategic perspective. I argue, that the benefits on the strategic level of investment in IT may take some time to materialize (Brynjolfsson and Hitt [4]). In particular, prior studies use different time lags that range from one to seven years and find inconsistent results (Brynjolfsson and Hitt [2], Lee and Kim [15]).

Kaplan and Norton introduced the method of the Balanced Scorecard which is a way of designing a performance measurement system that takes into account non-financial indicators. The Scorecard contains a variety of performance measurements, including financial performance, customer relations, internal business processes and learning and growth.

In this article, I try to find the best positive correlation between ERP system evaluation criteria and strategic performance of a small enterprise. In their publications, Kaplan and Norton attempted to get rid of the most commonly used system of management reporting on the basis of financial data (Kaplan and Norton [11]). They argued for achieving a balance between financial and non-financial data in management reporting. The four perspectives described above do not, however, restrict the Balanced Scorecard. According to Kaplan and Norton, the measurement system evolved into a strategic management system after a couple of years. They recognise that the basis for the Balanced Scorecard and the processes that occur in a company must be adjusted to each other periodically.

However, in my opinion, the role of the Balanced Scorecard in strategy formulation activity is wider. I maintain that the Balanced Scorecard may provide adequate feedback on the content of the implementation of an ERP system, and thus it can be used for strategic control in a company.
The strategic decision, as far as ERP system implementation is concerned, is based on the assessment of its potential advantages, resulting from the operation of such a system in the company. SMEs that are about to make a decision concerning the introduction of an ERP system tend to make an evaluation of the efficiency of the implementation (for example taking into consideration the level of fulfilment of the user's objectives) (Kłos et al. [12]). However, the process of the efficiency evaluation is very expensive, timeconsuming and typically followed by complicated analyzes. Bearing this in mind, there is a demand for developing a discussion for assessing the implementation of an ERP system using the Balanced Scorecard technique.

Additional value for SMEs can be defined by an effective implementation of an ERP system. SMEs with integrated IT systems also gain a further advantage in relation to the company because it enables them to have an insight into every aspect of its operation with a precise and correct evaluation of the company's financial situation. As a performance management and measurement tool, the BSC has been used to articulate and communicate the strategy of the business, and to help align organizational, cross-department, and individual initiatives to achieve common goals (Kaplan and Norton [10]). Milis and Mercken [19] suggest, that traditional capital investment assessment mechanisms, such as payback period, ARR (Accounting Rate of Return), ROI (Return on Investment), IRR (Internal Rate of Return), NPV (Net Present Value) were difficult to use to explain the associated intangible costs and benefits before and after the ERP system implementation. Clemons and Weber [6] pointed out that most of these mechanisms were at the stage of conceptualization and could not yet be accepted by the public. Therefore, Milis and Mercken [19] finally and enthusiastically recommended the use of the Balanced Scorecard as the proper assessment mechanism to evaluate the investment project of ERP system implementation.

Based on a review of the Balance Scorecard used in prior studies, I chose twenty eight ERP system evaluation criteria as the most important for my study (see Table 1). The introduction of ERP system should improve the level of the defined indicators in each perspective of BSC in the company. 
Table 1. The strategic objectives to achieved from the implementation of an ERP system and of the indicators, which help to measure it's in the company

(source: own study)

\begin{tabular}{|c|c|c|}
\hline $\begin{array}{l}\text { The strategic objectives to achieved } \\
\text { from the implementation of an ERP system } \\
\text { (modules: Contracts, Sales, Accounting, Mobile } \\
\text { sales) in each perspective of BSC in the company }\end{array}$ & & $\begin{array}{l}\text { Indicators, } \\
\text { which help to measure the defined objectives }\end{array}$ \\
\hline $\begin{array}{l}\text { the Customer Perspective } \\
\text { the objective: } \\
\text { increasing the efficiency } \\
\text { of customers relationship management }\end{array}$ & $\begin{array}{l}\text { 1) } \\
\text { 2) } \\
\text { 3) } \\
\text { 4) } \\
\text { 5) } \\
\text { 6) } \\
\text { 7) } \\
\text { 8) } \\
\text { 9) }\end{array}$ & $\begin{array}{l}\text { Customer relationship management cost/income } \\
\text { of sale } \\
\text { Sale's cost/income of sale } \\
\text { Number of customers } \\
\text { Premium Brand } \\
\text { Market share } \\
\text { Customer satisfaction (survey) } \\
\text { Customer loyalty (the re-purchase by customers) } \\
\text { Number of new products in the sale } \\
\text { Number of new products in relation to competition }\end{array}$ \\
\hline $\begin{array}{l}\text { the Learning and Growth Perspective } \\
\text { the objective: } \\
\text { increasing the productivity of the company }\end{array}$ & $\begin{array}{l}\text { 10) } \\
\text { 11) } \\
\text { 12) } \\
\text { 13) } \\
\text { 14) } \\
\text { 15) } \\
\text { 16) }\end{array}$ & $\begin{array}{l}\text { Productivity ratio of assets } \\
\text { Ratio of products, goods and materials } \\
\text { Participations rate of inventories in current assets } \\
\text { Participation rate of short-term receivables in current } \\
\text { assets } \\
\text { Participation rate of short-term investment in current } \\
\text { assets } \\
\text { Productivity ratio of total assets } \\
\text { Productivity ratio of fixed assets }\end{array}$ \\
\hline $\begin{array}{l}\text { the Financial Perspective } \\
\text { the objective: } \\
\text { increasing the profitability of the company and } \\
\text { improving the reliability of financial reporting }\end{array}$ & $\begin{array}{l}\text { 17) } \\
\text { 18) } \\
\text { 19) }\end{array}$ & $\begin{array}{l}\text { Ratio on Sale } \\
\text { Return on Assets } \\
\text { Return on Equity }\end{array}$ \\
\hline $\begin{array}{c}\text { the Business Process Perspective } \\
\text { the objective: } \\
\text { increasing the effectiveness of human resource } \\
\text { management (HRM) }\end{array}$ & $\begin{array}{l}\text { 20) } \\
\text { 21) } \\
\text { 22) } \\
\text { 23) } \\
\text { 24) } \\
\text { 25) } \\
\text { 26) } \\
\text { 27) } \\
\text { 28) }\end{array}$ & $\begin{array}{l}\text { Added value of human capital } \\
\text { Return of investment of human capital } \\
\text { Economic added value of human capital } \\
\text { Labor productivity } \\
\text { Equal opportunity } \\
\text { Work experiences } \\
\text { Employee's cost/ income } \\
\text { Salary's cost/income } \\
\text { HRM cost/income of sale }\end{array}$ \\
\hline
\end{tabular}




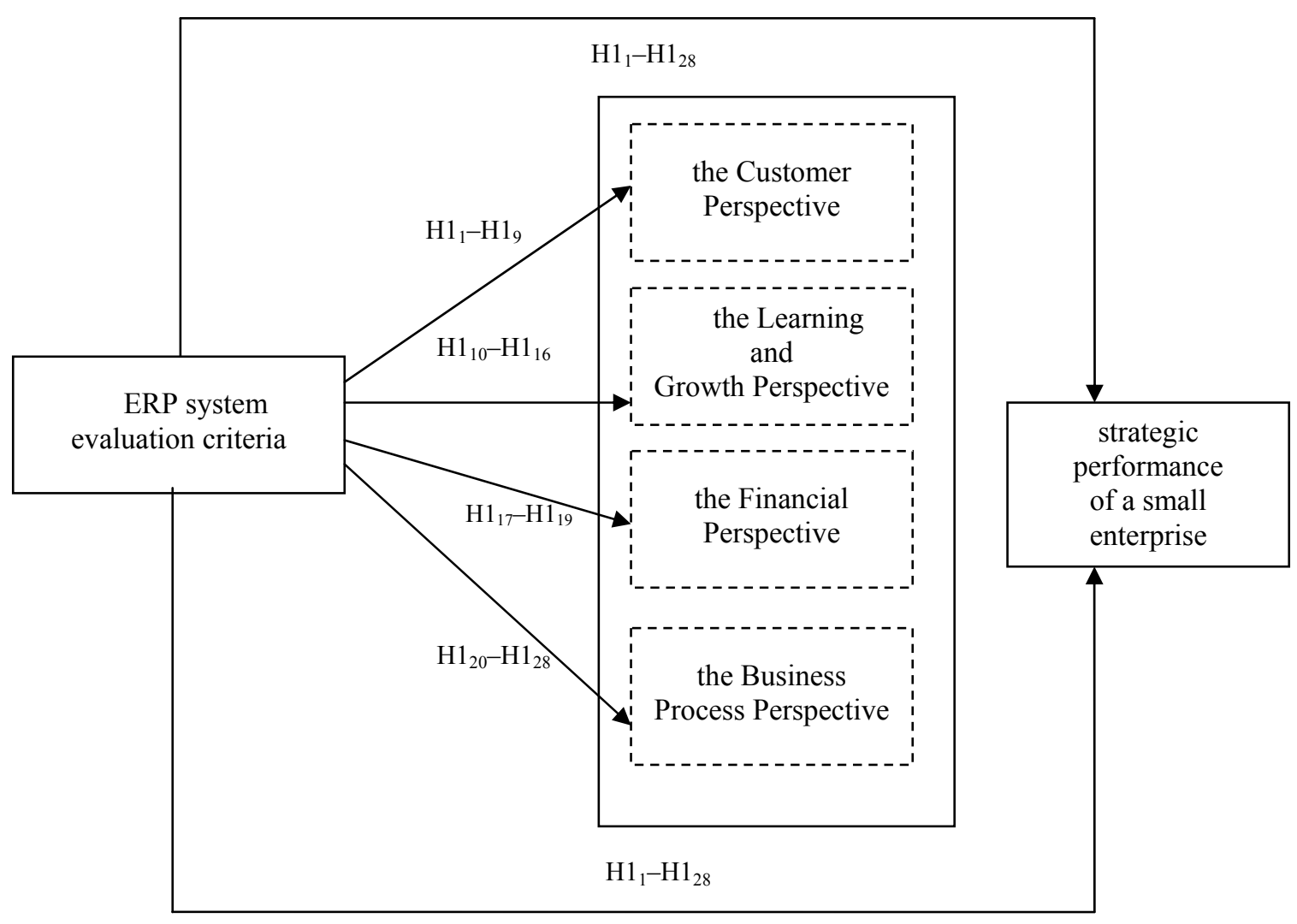

Figure 1. Research model and the hypotheses (source: own study)

The research hypotheses: $\mathrm{H}_{1}-\mathrm{H}_{28}$ are formulated: ERP system evaluation criteria (1-28) is positively correlated with strategic performance of a small enterprise.

My research model is presented in Fig. 1.

\section{$3 \quad$ Methodology}

In order to analyze the possibility of assessing the strategic impact of the post-implementation phase of an ERP using the BSC method, the survey examined the ERP implementation experiences of 6 small companies in Poland. Information on the indicators were obtained through direct interviews conducted in these companies. In order to present the possibility of hypotheses verification let me consider the small companies, that deal with providing services in the form of projects for both organizations and individual customers. The main areas of the companies correspond to the following functions: the sale, the supply, the order scheduling, the service, the accounting, human resources management, export/import transactions. Those companies completed, in 2008 , a project to im- plement an ERP system and the following modules were implemented: Contracts, Sales, Accounting, Admin, Mobile sales. The following strategic objectives were established to achieved from the implementation of an ERP system:

- increasing the efficiency of customers relationship management,

- increasing the productivity of the company,

- increasing the profitability of the company,

- improving the reliability of financial reporting,

- increasing the effectiveness of human resource management.

In Table 2 the values of defined indicators from six companies in 2011 are given. 
Table 2. Research results from six selected small enterprises, that completed, in 2008, a project to implement an ERP system

(source: own study)

\begin{tabular}{|c|c|c|c|c|c|c|c|c|}
\hline $\mathrm{BSC}$ & & Indicators/Company & E1 & E2 & E3 & E4 & E5 & E6 \\
\hline \multirow{9}{*}{$\begin{array}{l}\text { the Customer } \\
\text { Perspective }\end{array}$} & & $\begin{array}{l}\text { Customer relationship man } \\
\text { agement cost/income of sale }\end{array}$ & 0,01 & 0,04 & 0,02 & 0,01 & 0,01 & 0,02 \\
\hline & (2) & Sale's cost/income of sale & 0,02 & 0,04 & 0,03 & 0,01 & 0,01 & 0,02 \\
\hline & (3) & Number of customers & 24 & 48 & 35 & 28 & 14 & 22 \\
\hline & (4) & Premium Brand & - & - & - & - & - & - \\
\hline & (5) & Market share & - & - & - & - & - & - \\
\hline & (6) & $\begin{array}{l}\text { Customer satisfaction } \\
\text { (survey) }\end{array}$ & - & - & - & - & - & - \\
\hline & (7) & $\begin{array}{l}\text { Customer loyalty (the re- } \\
\text { purchase by customers) }\end{array}$ & - & - & - & - & - & - \\
\hline & (8) & $\begin{array}{l}\text { Number of new products } \\
\text { in the sale }\end{array}$ & 5 & 4 & 12 & 10 & 1 & 3 \\
\hline & (9) & $\begin{array}{l}\text { Number of new products } \\
\text { in relation to competition }\end{array}$ & - & - & - & - & - & - \\
\hline \multirow{7}{*}{$\begin{array}{l}\text { the Learning } \\
\text { and Growth } \\
\text { Perspective }\end{array}$} & (10) & Productivity ratio of assets & 1,5 & 1,7 & 1,2 & 1,3 & 0,9 & 1,5 \\
\hline & (11) & $\begin{array}{l}\text { Ratio of products, goods } \\
\text { and materials }\end{array}$ & 0,95 & 0,92 & 0,99 & 0,89 & 0,8 & 0,99 \\
\hline & (12) & $\begin{array}{l}\text { Participations rate of invent } \\
\text { tories in current assets }\end{array}$ & 0,26 & 0,33 & 0,15 & 0,32 & 0,14 & 0,28 \\
\hline & (13) & $\begin{array}{l}\text { Participation rate of short- } \\
\text { term receivables in current } \\
\text { assets }\end{array}$ & 0,6 & 0,4 & 0,7 & 0,3 & 0,4 & 0,6 \\
\hline & (14) & $\begin{array}{l}\text { Participation rate of short- } \\
\text { term investment in current } \\
\text { assets }\end{array}$ & 0,11 & 0,32 & 0,22 & 0,12 & 0,09 & 0,31 \\
\hline & (15) & $\begin{array}{l}\text { Productivity ratio of total } \\
\text { assets }\end{array}$ & 1,57 & 1,8 & 1,2 & 1,7 & 1,9 & 1,4 \\
\hline & (16) & $\begin{array}{l}\text { Productivity ratio of fixed } \\
\text { assets }\end{array}$ & 4,84 & 8,9 & 5,4 & 6,78 & 5,2 & 4,7 \\
\hline \multirow{3}{*}{$\begin{array}{l}\text { the Financial } \\
\text { Perspective }\end{array}$} & (17) & Ratio on Sale & 0,02 & 0,05 & 0,01 & 0,03 & 0,01 & 0,01 \\
\hline & (18) & Return on Assets & 0,06 & 0,09 & 0,06 & 0,04 & 0,03 & 0,04 \\
\hline & (19) & Return on Equity & 0,12 & 0,09 & 0,11 & 0,08 & 0,15 & 0,02 \\
\hline \multirow{9}{*}{$\begin{array}{l}\text { the Business } \\
\text { Process } \\
\text { Perspective }\end{array}$} & (20) & $\begin{array}{l}\text { Added value of human } \\
\text { capital }\end{array}$ & 109 & 89 & 120 & 110 & 109 & 112 \\
\hline & (21) & $\begin{array}{l}\text { Return of investment } \\
\text { of human capital }\end{array}$ & 0,13 & 0,09 & 0,07 & 0,06 & 0,13 & 0,15 \\
\hline & (22) & $\begin{array}{l}\text { Economic added value } \\
\text { of human capital }\end{array}$ & -44 & 10 & -23 & -24 & -54 & 8 \\
\hline & (23) & Labor productivity & 880 & 920 & 640 & 780 & 520 & 900 \\
\hline & (24) & Equal opportunity & - & - & - & - & - & - \\
\hline & (25) & Work experiences & - & - & - & - & - & - \\
\hline & (26) & Employee's cost/ income & 0,07 & 0,05 & 0,06 & 0,04 & 0,03 & 0,07 \\
\hline & (27) & Salary's cost/income & 0,08 & 0,06 & 0,07 & 0,05 & 0,04 & 0,08 \\
\hline & (28) & HRM cost/income of sale & 0,02 & 0,03 & 0,04 & 0,02 & 0,01 & 0,02 \\
\hline Output & Per & formance & 679 & 452 & 339 & 544 & 242 & 852 \\
\hline
\end{tabular}


Table 3. Research results from multivariate correlation analysis for the Customer Perspective in the BSC

(source: own study)

\begin{tabular}{|l|c|c|c|c|}
\hline & correlation & tolerance & $\mathrm{t}(3)$ & $\mathrm{p}$ \\
\hline (2) Sale's cost/income of sale & 0,902869 & 0,997828 & 3,626763 & 0,036075 \\
\hline (3) Number of customers & 0,854221 & 0,997828 & 2,796654 & 0,068042 \\
\hline (8) Number of new products in the sale & $-0,092813$ & 0,9894440 & $-0,160157$ & 0,882934 \\
\hline
\end{tabular}

Table 4. Research results from multivariate correlation analysis for the Learning and Growth Perspective in the BSC (source: own study)

\begin{tabular}{|ll|c|c|c|c|}
\hline & correlation & tolerance & $\mathrm{t}(3)$ & $\mathrm{p}$ \\
\hline$(11) \quad$ Ratio of products, goods and materials & 0,343906 & 0,645361 & 0,634355 & 0,570917 \\
\hline$(12) \begin{array}{l}\text { Participations rate of inventories in current } \\
\text { assets }\end{array}$ & 0,699687 & 0,630083 & 1,696264 & 0,188405 \\
\hline $\begin{array}{l}\text { (13) } \\
\quad \text { Participation rate of short-term receivables } \\
\text { in current assets }\end{array}$ & $-0,087515$ & 0,939400 & $-0,152164$ & 0,888715 \\
\hline (14) $\quad \begin{array}{l}\text { Participation rate of short-term investment } \\
\text { in current assets }\end{array}$ & 0,610619 & 0,886116 & 1,335509 & 0,273995 \\
\hline$(15) \quad$ Productivity ratio of total assets & 0,113475 & 0,897827 & 0,197822 & 0,855830 \\
\hline$(16) \quad$ Productivity ratio of fixed assets & 0,845865 & 0,934227 & 2,746694 & 0,070939 \\
\hline
\end{tabular}

Finally, based on the indicators values (Table 2), the research constructed values of correlation between an ERP system evaluation criteria (1-28) with strategic performance of a small enterprise and with net benefits of a small enterprise for each of four perspective.

\section{$4 \quad$ Data analysis and model testing}

In order to verify the research hypotheses it is used multivariate correlation analysis for each of the defined perspectives in the BSC. In the Table 3-6 the research results are given:
- For the Customer Perspective (Table 3)

In the Customer Perspective in the BSC: (2) Sale's cost/income of sale and (8) Number of customers (the defined ERP system evaluation criteria) are the most positively correlated with strategic performance of a small enterprise $\left(\mathrm{H}_{1}-\mathrm{H} 1_{9}\right)$.

- For the Learning and Growth Perspective (Table 4) In the Learning and Growth Perspective in the BSC: (12) Participations rate of inventories in current assets and (16) Productivity ratio of fixed assets (the defined ERP system evaluation criteria) are the most positively correlated with strategic performance of a small enterprise $\left(\mathrm{H} 1_{10}-\mathrm{H} 1_{16}\right)$. 
Table 5. Research results from multivariate correlation analysis for the Customer Perspective in the BSC

(source: own study)

\begin{tabular}{|ll|c|c|c|c|}
\hline & correlation & tolerance & $\mathrm{t}(3)$ & $\mathrm{p}$ \\
\hline$(17) \quad$ Ratio on Sale & $-0,123849$ & 0,459198 & $-0,19487$ & 0,863498 \\
\hline$(18) \quad$ Return on Assets & 0,053447 & 0,461503 & 0,08430 & 0,940493 \\
\hline$(19) \quad$ Return on Equity & $-0,796534$ & 0,989239 & $-1,83950$ & 0,207213 \\
\hline
\end{tabular}

Table 6. Research results from multivariate correlation analysis for the Business Process Perspective in the BSC (source: own study)

\begin{tabular}{|ll|c|c|c|c|}
\hline & & correlation & tolerance & $\mathrm{t}(3)$ & $\mathrm{p}$ \\
\hline$(20) \quad$ Added value of human capital & 0,032976 & 0,998731 & 0,065989 & 0,950553 \\
\hline$(21) \quad$ Return of investment of human capital & $-0,013361$ & 0,803417 & $-0,02314$ & 0,982989 \\
\hline$(22) \quad$ Economic added value of human capital & $-0,483507$ & 0,793708 & $-0,95672$ & 0,409286 \\
\hline$(23) \quad$ Labor productivity & $-0,837361$ & 0,370455 & $-2,65317$ & 0,076786 \\
\hline (26) & Employee's cost/ income & 0,273820 & 0,465282 & 0,49312 & 0,655768 \\
\hline$(27) \quad$ Salary's cost/income & 0,273820 & 0,465282 & 0,49312 & 0,655768 \\
\hline$(28) \quad$ HRM cost/income of sale & 0,074042 & 0,983620 & 0,12860 & 0,905813 \\
\hline
\end{tabular}

- For the Financial Perspective (Table 5)

In the Financial Perspective in the BSC it cannot be defined ERP system evaluation criteria, that are positively correlated with strategic performance of a small enterprise $\left(\mathrm{H} 1_{17}-\mathrm{H} 1_{19}\right)$.

- For the Business Process Perspective (Table 6)

In the Business Process Perspective in the BSC (26) Employee's cost/ income and (27) Salary's cost/income (the defined ERP system evaluation criteria) are the most positively correlated with strategic performance of a small enterprise $\left(\mathrm{H}_{20}-\mathrm{H} 1_{28}\right)$.
It is found the most significant relationship between the output of the research hypothesis and the defined ERP system evaluation criteria in the each of four BSC perspectives. Thus enables me to built the space to measure the strategic effects of the implementation of ERP systems for small businesses (see Fig. 2). 


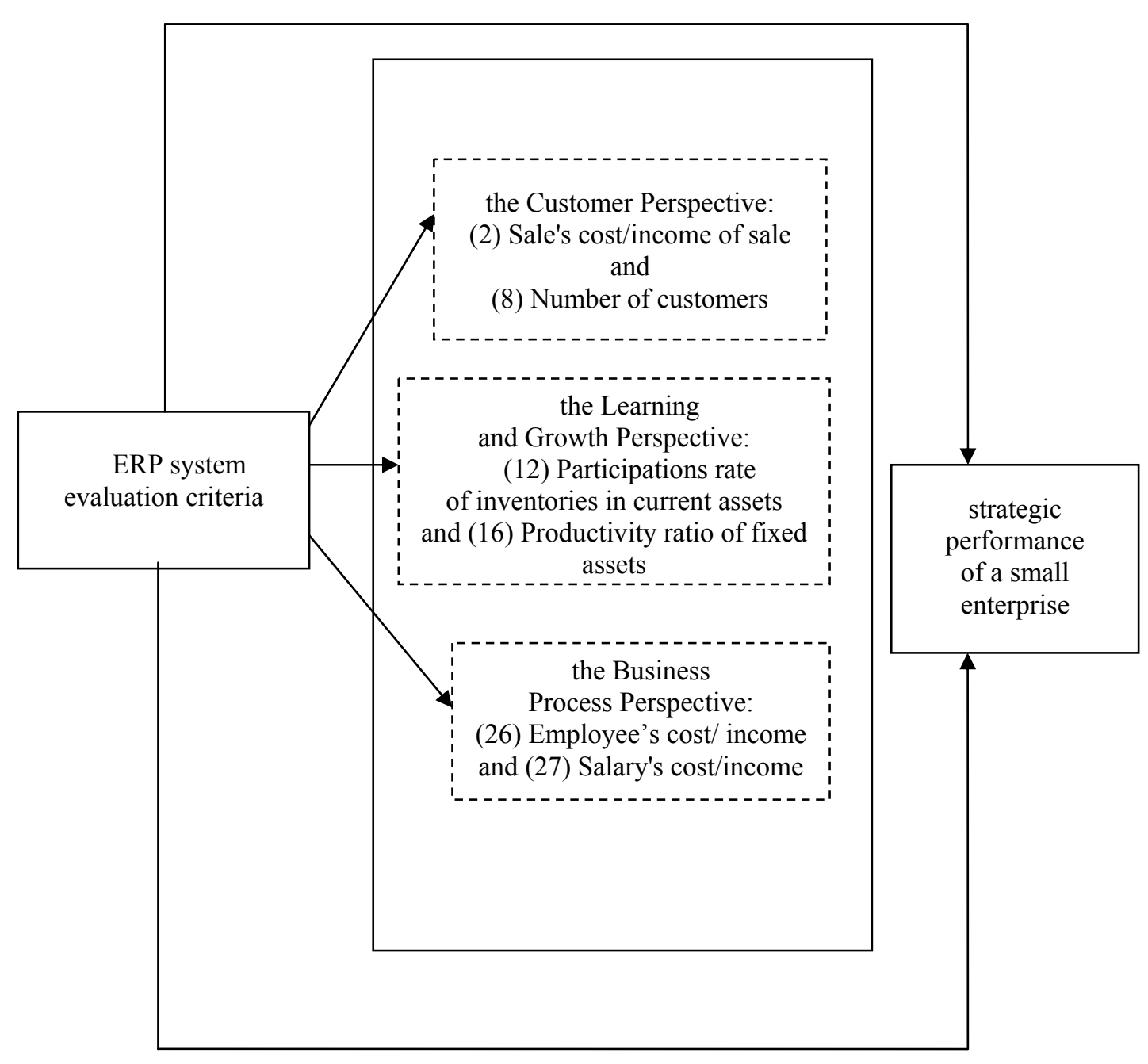

Figure 2. The space to measure the strategic effects of the implementation of ERP systems for small businesses (source: own study)

Further work is carried out to build a broader database to find a better space to assessment of the implementation of the ERP system.

For a more detailed analysis of the applicability of the proposed approach a case study is presented. The main areas of the company (E1) correspond to the following functions: the sale, the supply, the order scheduling, the service, the accounting, human resources management, export/import transactions. This company completed, in 2008, a project to implement an ERP system and the following modules were implemented: Contracts, Sales, Accounting, Admin, Mobile sales. The author assesses the implementation of an ERP system in accordance with the defined space to measure the strategic effects of the implementation of ERP systems for small businesses (see Fig. 2).
The Customer Perspective: the strategic objective to achieve: increasing the efficiency of customers relationship management, the indicator: the number of customers since the implementation of an ERP system (since 2008).

So, the number of customers since the implementation of an ERP system (since 2008) and a forecast of the number of customers for the years 2012-2014 is given (see Fig. 3).

The strategic goal of an ERP system is the transformational capability of the organization to meet the new needs of its customers and the needs of any new customers. This also includes strategic partnering with customers - carried out between a network of about 300 stores. 


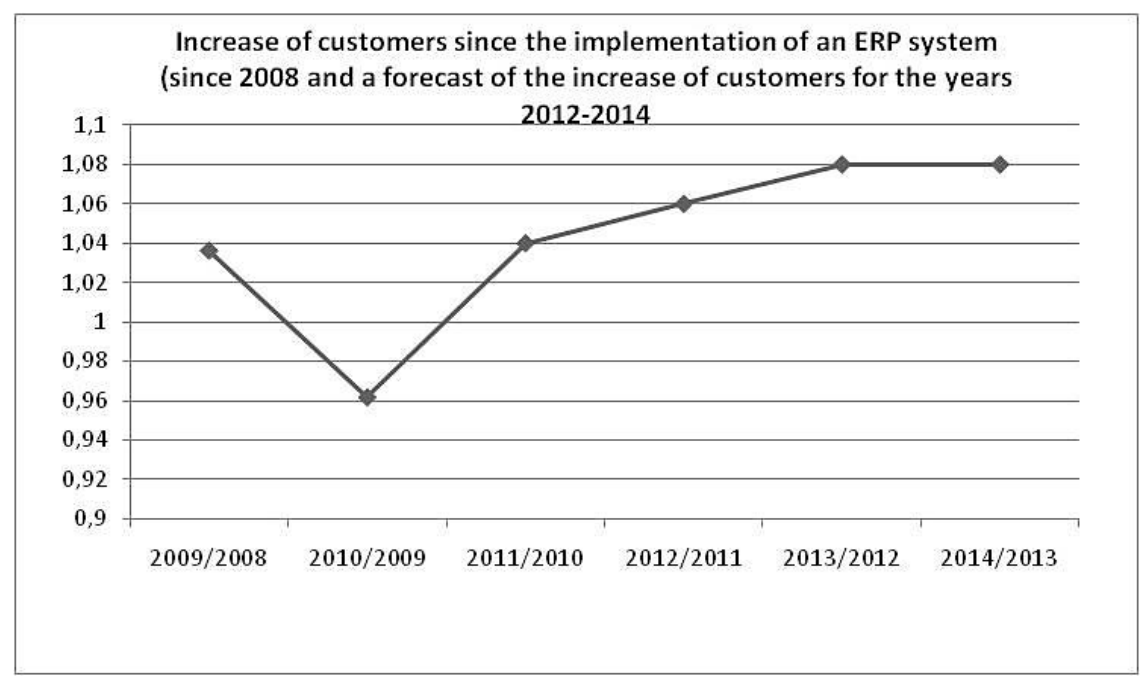

Figure 3. Increase of customers since the implementation of an ERP system (since 2008) and a forecast of the increase of customers for the years 2012-2014

(source: own study)

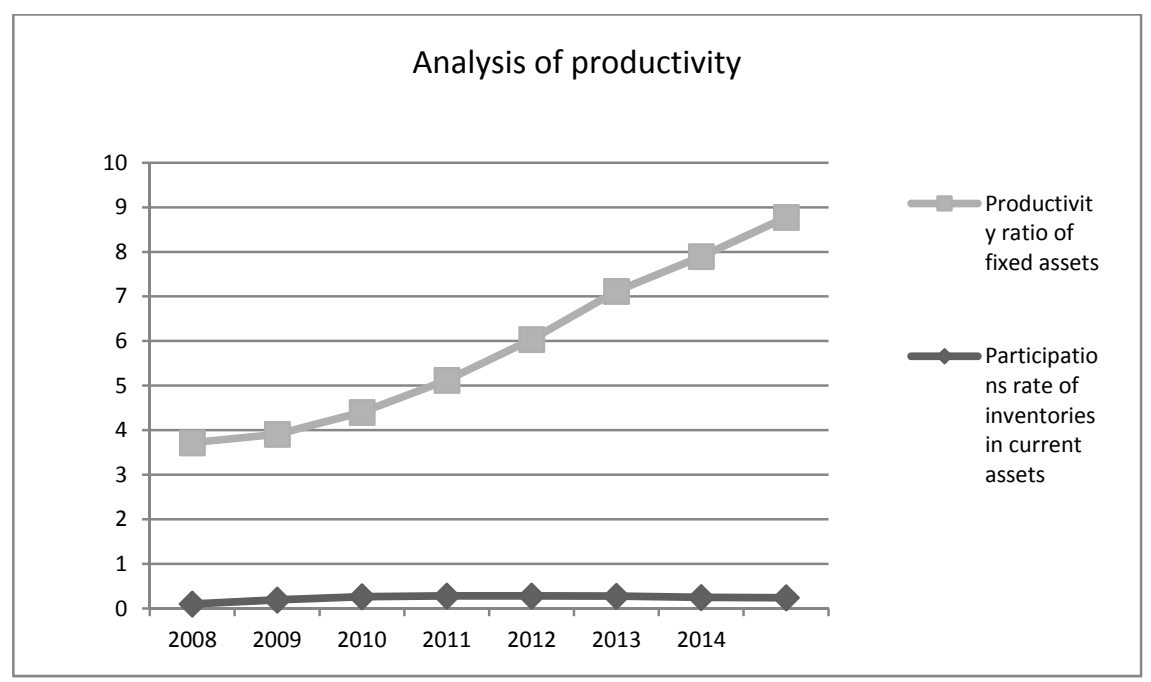

Figure 4. The values of productivity indicators since the implementation of an ERP system (since 2008) and the forecast values of productivity indicators for the years 2012-2014

(source: own study)

Also the following issues have been defined in this network:

- a lack of communication between the network partners and suppliers,

- an inability to transmit orders to suppliers for the purchase in a uniform manner,

- an inability to download electronic invoices in a uniform manner,

- an inability to send data on promotions, newsletters and current prices,
- a lack of opportunities to exchange information among its members such as through the ability to create surveys, newsletters,

- a lack of reporting on the performance of the network.

Extending the functionality of the ERP system for Business to Business solutions can help the organization to solve these problems and correct potential future problems with customers. 


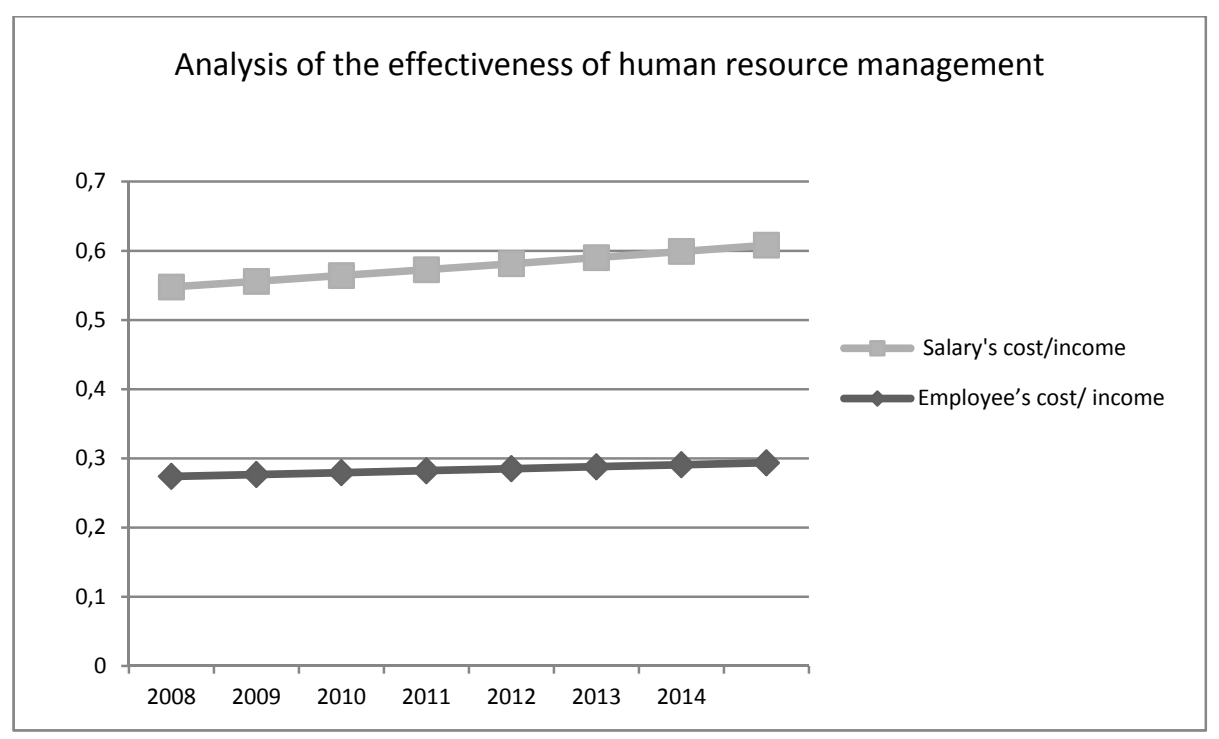

Figure 5. The values of the effectiveness of human resource management since the implementation of an ERP system (since 2008) and the forecast values for them for the years 2012-2014

(source: own study)

The Innovation and Learning Perspective: the strategic objective to achieve: increasing the productivity of the company, the indicators: participations rate of inventories in current assets and productivity ratio of fixed assets (since 2008).

So, the values of defined indicators since the implementation of an ERP system (since 2008) and the forecast value for the years 2012-2014 are formulated (see Fig. 4).

The implemented ERP system can be extended with additional functionality that will enable the creation a Business to Business system. The task of the new system will be to automate logistics processes within the company's network.

The implemented ERP system can be extended with additional functionality that will enable to create a Business to Business system. The task of the new system will automate logistics processes within the company's network:

- automatically send orders to suppliers for a purchase of a unified manner,

- the automatic retrieval of electronic invoices in a uniform way,

- the automatic routing of data on promotions, newsletters, current prices,

- the automatic exchange of information among its members, for example, through the ability to create surveys, newsletters,

- reporting on the performance of the network.
The Business Process Perspective: the strategic objective to achieve: increasing the effectiveness of human resource management, the indicators: employee's cost/ income and salary's cost/income, which help to measure the defined objective: added value of human capital.

So, the value of the defined indicators since the implementation of an ERP system (since 2008) and the forecast value for the years 2012-2014 (see Fig. 5).

In accordance with the strategic goals: extending the functionality of the ERP system for Business to Business solutions allows for the following business processes to be defined:

- the sales process - improving the exchange of commercial information within the network - between members and the network operator,

- comprehensive data exchange: the exchange of purchase orders, sales invoices exchange, registration of invoices,

- the promotional process - generating and distributing data on promotions, newsletters, current prices within the network,

- customer relationship management - improving the exchange of commercial information within the network - between members and the network operator,

- comprehensive data exchange: exchange regarding customer satisfaction surveys, newsletters, 
- the process of information management and reporting - data exchange on how to optimize business processes and partners, all through the mechanisms of effective management information provided by multilevel analysis.

In the real case study, the ERP system has impacted enhanced revenue opportunities and improved market positioning. SMEs, unlike large companies, do not have the capital to purchase such tools, as well as full implementation of an ERP system. The postimplementation phase of an ERP should improve the level of the defined indicators in each perspective of the BSC in the company. The analysis shows that in a given company there is a need to develop ERP system functionality.

It was demonstrated through a real case study that the Balanced Scorecard may be an appropriate approach for defining the success of ERP system and establishing the trends of a firm's development in accordance with the strategic goal. It is hoped that this case study will help to identify some of the capacity of the system ERP.

\section{References}

[1] Al-Mashari M., Al-Mudimigh A., Zairi M. - ERP: A Taxonomy of Critical Factors [in] European Journal of Operational Research 146, 2003, pp. 352-364.

[2] Aral, S., Weill, P. - IT Assets, Organizational Capabilities and Firm Performance: How Resource Allocations and Organizational Differences Explain Performance Variations [in] Organization Science, 18(5), 2007, pp. 763-780.

[3] Austin R., Sole D., Cotteleer M. - Harley-Davidson Motor Co.: Enterprise Software Selection. Harvard Business School Publishing 9-600-006, 1999.

[4] Brynjolfsson, E., Hitt L.M. - Beyond the Productivity Paradox: Computers Are the Catalyst for Bigger Changes [in] Communications of the ACM, 41(8), 1998, pp. 49-55.

[5] Brynjolfsson, E., Hitt, L. - Computing Productivity: Firm-Level Evidence [in] The Review of Economics and Statistics, 85(4), 2003, pp.793-808.

[6] Clemons, E.K., Weber B.W. - Strategic Information Technology Investments: Guidelines for Decision Making [in] Journal of Management Information Systems, 7(2), 1990, pp. 10-31.
[7] Davenport T.H. - Putting the Enterprise into the Enterprise System [in] Harvard Business Review 76(4), 1998, pp. 121-131.

[8] Dehning, B., Richardson, V.J. - Returns on Investments in Information Technology: A Research Synthesis [in] Journal of Information Systems, 16(1), 2002, pp. 7-30.

[9] Gattiker T.F., Goodhue, D.L. - What Happens after ERP Implementation: Understanding the Impact of Interdependence and Differentiation on PlantLevel Outcomes [in] MIS Quarterly, 29(3), 2005, pp. 559-585.

[10] Kaplan R.S., Norton D.P. - The Balanced Scorecard: Translating Strategy into Action. Harvard Business School Press, Boston, MA 1996.

[11] Kaplan S., Norton D.P. - Putting the Balanced Scorecard to Work. Harvard Business Review 1993.

[12] Kłos S., Patalas J., Banaszak Z. - The Role of ERP in the Transfer of Technology and Know-How. Organization Support System, Katowice 2004.

[13] Kohli R., Grover V. - Business Value of IT: An Essay on Expanding Research Directions to Keep Up with the Times [in] Journal of the Association for Information Systems, 9(1), 2008, pp. 23-39.

[14] Lassila K.S., Brancheau J.C. - Adoption and Utilization of Commercial Software Packages: Exploring Utilization Equilibria, Transitions, Triggers and Tracks [in] Journal of Management Information Systems, 16(2), 1999, pp. 63-90.

[15] Lee, S., Kim, S.H. - A Lag Effect of IT Investment on Firm Performance [in] Information Resources Management Journal, 19(1), 2006, pp. 43-69.

[16] Lipe M.G., Salterio S.E. - The Balanced Scorecard: Judgmental Effects of Common and Unique Performance Measures [in] The Accounting Review,73(3), 2000, pp. 283-298.

[17] Markus M.L., Tanis C. - The enterprise systems experience - from adoption to success [in] Framing the Domains of IT Research: Glimpsing the Future Through the Past (ed. R.W. Zmud), Pinnafles Educational Resources Inc., Cincinnati, OH, 2000, pp. 173-207.

[18] Mata F.J., Fuerst W.L., Barney J.B. - Information Technology and Sustained Competitive Advantage: A Resource-Based Analysis. MIS Q 19(4), 1995, pp. 487-505. 
[19] Milis, K., Mercken, R. - The Use of the Balanced Scorecard for the Evaluation of Information and Communication Technology Projects [in] International Journal of Project Management, 22(2), 2004, pp. 87-97.

[20] Patalas-Maliszewska J., Krebs I. - A Model of Employee Selection for SME Based on Innovation Transfer [in] Business Information Systems Workshops: BIS 2010 International Workshops: revised paper (eds. W. Abramowicz, R. Tolksdorf, K. Węcel), Berlin - Heidelberg: Springer-Verlag, (Lecture Notes in Business Information Processing; 57, 2010, pp. 57-66.

[21] Patalas-Maliszewska J., Krebs I. - Model of Innovation Transfer is Small and Medium Enterprises (SME) [at] Advances in Production Engineering APE 2010, proceedings of the 5th international conference, Warsaw University of Technology, Faculty of Production Engineering, 2010.
[22] Poston R., Grabski S. - Financial Impacts of Enterprise Resource Planning Implementations [in] International Journal of Accounting Information Systems, 2(4), 2001, pp. 271-294.

[23] Rosemann M. - Evaluating the Management of Enterprise Systems with the Balanced Scorecard [in] IT Evaluation Methods and Management (ed. W. Van Grembergen), Idea Group Publishing, Hershey, USA 2001, pp. 171-184.

[24] Rosemann M., Wiese J. - Measuring the Performance of ERP Software - a Balanced Scorecard Approach [at] Proceedings of the 10th Australasian Conference on Information Systems, Wellington 1999, pp. 773-784.

[25] Staehr L., Shanks G., Seddon, P.B. - Understanding the Business Benefits of Enterprise Resource Planning Systems. Paper presented at the 8th Americas conference on information systems Dallas, USA, August 9-11, 2002. 